\title{
Natural Products as Sources of New Drugs for the Regulation of Mast Cell Activation +
}

\author{
Roberto Coll, María Laura Mariani and Alicia Penissi * \\ IHEM-FCM-UNCuyo, Facultad de Ciencias Médicas, Universidad Nacional de Cuyo, \\ M5500 Mendoza, Argentina \\ * Correspondence: aliciapenissi@gmail.com; Tel.: +54-0261-413-5000 \\ + Presented at the 2nd Molecules Medicinal Chemistry Symposium (MMCS): Facing Novel Challenges in \\ Drug Discovery, Barcelona, Spain, 15-17 May 2019.
}

Published: 16 August 2019

Keywords: mast cells; natural products; olive oil

Taking into account that the identification of novel molecules for the effective treatment of inflammatory and immune diseases is one of the main present medical needs and one of the major goals of the pharmaceutical industry, the aim of our work is intended to provide new therapeutic strategies and a deeper understanding of the mechanism of action of new drugs related to such disorders. Our research team has shown that some natural and synthetic lactones developed by our laboratory, as well as phenols isolated from virgin olive oil, inhibit mast cell activation induced by immune and non-immune pathways, thus acting as mast cell stabilizers. Recently, we have started to explore whether the application of these mast cell stabilizers will be useful for prevention and/or treatment of mast cell-mediated disorders.

Diseases investigated include: Peptic ulcer, neuropathic pain, tumor development, multiple sclerosis, and allergic asthma. Our laboratory investigates the role of mast cells in such pathologies and the pharmacological regulation of mast cell activation by conducting studies on animal and human mast cells, and by analyzing specimens derived from patients with mast cell disorders. Biochemical, chemical, cell biology, molecular biology, and a variety of microscopic techniques were used, as well as animal models for the investigated diseases in which mast cells are involved. These studies may lead to an increased understanding of these disorders and may contribute to new preventive measures, diagnosis, and treatments.

(C) 2019 by the authors. Licensee MDPI, Basel, Switzerland. This article is an open access article distributed under the terms and conditions of the Creative Commons Attribution (CC BY) license (http://creativecommons.org/licenses/by/4.0/). 